\title{
CYP1A2 Substrate
}

National Cancer Institute

\section{Source}

National Cancer Institute. CYP1A2 Substrate. NCI Thesaurus. Code C120265.

Any substance acted upon by cytochrome P450 1A2. 